\title{
RANCANG BANGUN SMART TRASH CAN BERBASIS IOT (INTERNET OF THINGS) UNTUK PETUGAS SAMPAH PERUMAHAN
}

\author{
(Design of Smart Trash Can Based on loT (Internet Of Things) for Housing Waste \\ Officers)
}

\author{
Muh. Ardian Saputra, I Gde Putu Wirarama Wedashwara Wirawan*, Ariyan Zubaidi \\ Prodi Teknik Informatika, Universitas Mataram \\ Jl. Majapahit 62, Mataram, Lombok NTB, INDONESIA \\ Email: ardianputra2507@gmail.com, [wirarama, zubaidi13] @unram.ac.id
}

\begin{abstract}
Waste is the result of waste / output from all human activities. Every day humans produce waste, both organic and inorganic waste which have various shapes and types. No wonder these problems are also found in many housing areas. One of the housing in Mataram City is Babakan Permai housing which is located in Babakan village, Sandubaya subdistrict, Mataram City. The handling of waste problems in Babakan Permai Housing is handled by scheduling garbage collection at each house. Garbage is taken every 2 times a week by residential garbage officers. This has a drawback, namely that the potential for accumulation of garbage in each house increases. The accumulation of garbage is very disturbing to residents in the surrounding environment both in terms of cleanliness and health. Thus, this problem can be overcome by making a Smart Trash Can tool that can make it easier for garbage workers in housing. This final project is a prototype of a smart trash can that can monitor trash bins. This can be done by applying the concept of loT (Internet of Things) which utilizes the internet. The protocol used in loT is MQTT (Message Queuing Telemetry Transport) which is lightweight message and is designed for devices with limited resources. With the loT concept, monitoring of trash cans is carried out using several sensors such as the use of a weight sensor (load cell) as a detection of waste weight, the HX711 module as a load cell weight value conversion and a magnetic switch sensor to determine the open / cover of the trash bin connected with a microcontroller.
\end{abstract}

Keywords: Internet of Things, Load Cell, Sensor Magnetic Switch, Smart Trash Can, Perumahan, WeMos, Microcontroller, MQTT.

*Penulis Korespondensi

\section{Pendahuluan}

Sampah merupakan salah satu permasalahan yang dihadapi oleh banyak kota di Indonesia. Semakin tinggi jumlah penduduk dan aktivitasnya, membuat volume sampah semakin meningkat. Ketika kapasitas bak tempat sampah tersebut sudah melebihi batas maksimun, tempat sampah harus segera diangkut oleh petugas sampah. Tempat sampah yang tidak segera diangkut dapat menyebabkan masalah seperti bau tidak sedap, lingkungan menjadi kotor, sampah menjadi menumpuk hal ini dapat mengganggu lingkungan menjadi tidak nyaman [1].

Perumahan merupakan kelompok rumah yang berfungsi sebagai lingkungan tempat tinggal atau hunian yang dilengkapi dengan prasarana lingkungan yaitu kelengkapan dasar fisik lingkungan, misalnya penyediaan air minum, pembuangan sampah, tersedianya listrik, telepon, jalan, yang memungkinkan lingkungan pemukiman berfungsi sebagaimana mestinya [2]. Salah satu perumahan yang ada di Kota
Mataram adalah perumahan Babakan Permai yang terletak di kelurahan Babakan, kecamatan Sandubaya, Kota Mataram. Perumahan Babakan Permai di bangun pada tahun 1995 dan memiliki luas tanah sebesar $13,775 \mathrm{~m} 2$. Perumahan ini sebagian besar di huni oleh pegawai yang bekerja di sektor formal seperti pegawai negeri sipil, TNI/Polri, pegawai bank dan pekerja profesi seperti dokter.

Penanganan masalah sampah di Perumahan Babakan Permai ditangani dengan cara penjadwalan untuk pengambilan sampah pada masing-masing rumah. Sampah di ambil setiap 2 kali seminggu oleh petugas sampah perumahan. Hal ini memiliki kekurangan yaitu potensi penumpukan sampah pada tiap rumah meningkat. Penumpukan sampah sangat mengganggu warga di lingkungan sekitar baik dari segi kebersihan maupun kesehatan.

Permasalahan sampah seperti yang telah diuraikan dapat dihindari dengan cara memberi informasi kepada petugas sampah di perumahan agar petugas sampah dapat segera bertindak. Hal tersebut 
dapat diwujudkan dengan menggunakan teknologi internet yang memanfaatkan konsep loT (Internet Of Things) yang dimana loT ini merupakan konsep untuk menghubungkan setiap objek fisik dengan internet sehingga dapat saling berkomunikasi dan bertukar informasi, dengan mengunakan konsep loT dapat memungkinkan untuk memonitoring suatu tempat sampah dan mengefektifkan kapan sampah bisa diangkut berdasarkan berat maksimum dan penuh sampah menggunakan sensor berat dan sensor mc-38 [3].

Berdasarkan hal - hal yang telah dipaparkan, akan di bangun sebuah sistem smart trash can berbasis loT untuk monitoring tempat sampah pada lingkungan perumahan agar petugas sampah dapat mengetahui informasi-informasi keadaan tempat sampah. Penerapan loT dengan sensor - sensor yang diperlukan serta penggunaan protokol MQTT dapat membuat sebuah sistem web yang berguna bagi petugas sampah.

\section{TinjauAn PUStaka}

Berikut merupakan tinjauan pustaka dari penelitian yang terkait yang telah dilakukan sebelumnya, sebagai bahan acuan untuk melakukan penelitian ini.

Pada penelitian terkait sebelumnya [4] dilakukan penelitian dengan membuat tempat sampah pintar yang digunakan untuk menimbang dan mengenali sampah sehingga dapat mempermudah pengelola bank sampah untuk melakukan penimbangan sampah dan identifikasi sampah yang berbasis komputer dan langsung tersimpan dalam database. Tempat sampah pintar ini menggunakan QR code, sensor berat (load cell), dan arduino uno yang dalam hal menimbang sampah dan identifikasi sampah. Rancangan kerja sistem tempat sampah pintar ini memanfaatkan webcam, sensor load cell dan arduino uno. Arsitektur tempat sampah pintar berbasis komputer ini yaitu dengan menghubungkan alat - alat yang ada yaitu load sensor, IC amplifier INA 125P, arduino, komputer, webcam, dll. Arduino diprogram agar dapat mengontrol alat - alat dan sensor tersebut, arduino merupakan 'otak' yang mengatur data yang diterima dari dan load cell sensor. Selain itu arduino juga berfungsi menerima perintah dan mengirim data yang diinstruksikan oleh aplikasi. Serta webcam yang berfungsi mengambil data QR code. Pada hasil uji coba pengukuran berat dengan pembacaan load cell didapat rata-rata kesalahan 1,33\%, maka aplikasi ini dapat bekerja dengan baik [4]. Persamaan dari penelitian terkait dengan penelitian yang dilakukan adalah menggunakan sensor load cell sebagai peninmbang beban sampah. Sedangkan perbedaan penelitian terkait dengan penelitian yang dilakukan yaitu, penelitian yang dilakukan menggunakan modul HX711 yang dihubungkan ke sensor berat sebagai konversi nilai berat, sensor magnetic switch sebagai notifikasi status tutup/bukaan tempat sampah, WeMos D1 (R2) sebagai mikrokontroler dan menerapkan konsep IoT dengan protokol MQTT.

Pada penelitian terkait sebelumnya [5] dilakukan penelitian dengan teknologi yang digunakan dalam memelihara kebersihan, dalam hal ini adalah tempat sampah pintar. Tujuan dari pembuatan sebuah sistem otomatisasi pemberitahuan pada kotak sampah adalah untuk memberikan pemberitahuan apabila kotak sampah telah penuh sehingga mencegah terjadinya penumpukan sampah yang menjadi penyebab terjangkitnya bibit penyakit. Penelitian ini dilakukan dengan empat tahap proses yaitu analisis masalah dan kebutuhan, perancangan dan implementasi, serta pengujian. Pada bagian ini diuraikan Analisis masalah dan kebutuhan, sedangkan perancangan dan implementasi serta pengujian diuraikan dalam sub judul tersendiri. Tempat sampah pintar ini memiliki sensor ultrasonik yang digunakan untuk mendeteksi suatu benda atau objek berbasis mikrokontroler WeMos D1 Mini yang dapat mendeteksi apakah kotak sampah telah penuh atau belum. Kemudian menggunakan Blynk (platform) blynk adalah platform untuk aplikasi OS Mobile (iOS dan Android) yang bertujuan untuk kendali modul WeMos D1 mini, dan Arduino Uno IDE. Software arduino ini digunakan untuk memprogram Arduino Uno agar dapat terkoneksi dengan sensor dan modul yang dibutuhkan dan mengunggah kode program ke dalam perangkat WeMos D1 Mini [5]. Persamaan dari penelitian terkait dengan penelitian yang dilakukan adalah menerapkan konsep tempat sampah pintar, Untuk perbedaannya, pada penelitian yang akan digunakan menggunakan sensor berat (load cell) dan Hx711 sebagai konversi nilai berat dan menerapkan konsep loT dengan protokol MQTT serta dilakukan pencatatan data ke dalam database yang dapat dimonitor dengan sistem berbasis web.

Pada penelitian terkait sebelumnya [6] dilakukan penelitian dengan membuat sebuah tempat sampah pintar yang mampu mengontrol dan mengirimkan data saat tempat sampah sudah mengalami kepenuhan, sehingga mempemudah petugas kebersihan untuk melakukan pembersihan sampah tanpa perlu menghabiskan waktu. Pertukaran data akan menggunakan sebuah protokol MQTT, sebuah protokol yang digunakan untuk implementasi 
Internet of Things, dan sebuah sensor pengukur jarak yaitu sensor ultrasonik HY-SRF05, Arduino Uno, dan modul wifi ESP8266. Hasil pengukuran sensor ultrasonik dapat dipengaruhi oleh media yang terdeteksi oleh sensor itu sendiri. Semakin jauh jarak objek yang dideteksi oleh sensor ultrasonik, maka akan semakin lama waktu yang diperlukan sensor ultrasonik untuk memantulkan gelombang kembali ke sensor. Pertukaran data menggunakan protokol MQTT pun dapat dilakukan walaupun nilai delay yang besar dan nilai throughput yang kecil tidak sesuai dengan standar TIPHON, walaupun nilai yang didapatkan delay dan throughput tidak sesuai standar, namun nilai packet loss tetap $0 \%$ yang artinya akurasi pengiriman data adalah $100 \%$. [6]. Persamaan dari penelitian terkait dengan penelitian yang dilakukan adalah pada penggunaan protokol MQTT, Untuk perbedaannya, pada penelitian yang akan dilakukan menggunakan sensor berat (load cell), dan HX711 sebagai konversi nilai berat, sensor magnetic switch sebagai notifikasi status tutup/bukaan tempat sampah serta meggunakan WeMos D1 (R2) sebagai mikrokontroler.

Pada penelitian terkait sebelumnya [7] dilakukan penelitian dengan merancang tempat sampah otomatis menggunakan mikrokontroler AT Mega 328, sensor HC-SR04, LED dan LCD.Sensor HC-SR04 digunakan untuk mendeteksi keberadaan manusia dan mendeteksi kapasitas tempat sampah menggunakan gelombang ultrasonik, Buzzer di gunakan untuk pemberitahuan suara jika tempat sampah telah penuh dan LCD untuk menampilkan data. Hasil yang diperoleh dari pengujian sistem adalah tempat sampah berhasil dalam membuka dan menutup secara otomatis serta mendeteksi kapasitas tempat sampah dan menampilkan ke LED sesuai dengan fungsi sistem [7]. Persamaan dari penelitian terkait dengan penelitian yang dilakukan adalah menerapkan konsep tempat sampah pintar, Untuk perbedaannya yaitu penelitian yang akan dilakukan menggunakan sensor berat (load cell) dan Hx711 sebagai konversi nilai berat, sensor magnetic switch sebagai notifikasi status tutup/bukaan tempat sampah dan menerapkan konsep IOT dengan protokol MQTT dan dilakukan pencatatan data ke dalam database yang dapat dimonitor dengan sistem berbasis web serta menggunakan mirkrokontroler WeMos D1 (R2).

\section{Metode Penelitian}

\subsection{Analisis Kebutuhan Sistem}

Pada tahap analisis kebutuhan sistem akan dilakukan analisis terhadap kebutuhan dari sistem Smart Trash Can Berbasis IoT Untuk Petugas Sampah
Perumahan. Analisis yang dilakukan meliputi analisis kebutuhan alat dan bahan yang diperlukan dalam pembuatan sistem. Dalam perancangan sistem Smart Trash Can Berbasis IoT Untuk Petugas Sampah Perumahan, ada beberapa alat dan bahan yang dibutuhkan, yaitu:

\section{Alat Penelitian}

Alat-alat yang diperlukan dalam penelitian ini dibagi menjadi dua yakni perangkat keras dan perangkat lunak antara lain sebagai berikut :

a. Perangkat Keras

- Laptop/PC untuk aktivitas pembuatan code aplikasi.

- 1 buah WeMos D1 (R2) sebagai mikrokontroler.

- 1 set kabel jumper.

- 1 buah sensor berat sebagai deteksi berat sampah.

- 1 buah modul HX711 untuk konversi nilai berat loadcell.

- 1 buah sensor magnetic switch sebagai deteksi tutup/bukaan tempat sampah.

- 1 buah adapter untuk menghubungkan mikrokontroler dengan sumber daya.

b. Perangkat Lunak

- Sistem operasi Windows 10.

- Arduino IDE sebagai code editor untuk mikrokontroler.

- Visual Studio Code sebagai code editor untuk web.

- XAMPP sebagai server dan tempat untuk menyimpan data.

- Browser untuk mengakses halaman web.

2. Bahan Penelitian

Adapun bahan-bahan yang diperlukan dalam penelitian ini sebagai berikut:

a. Tempat sampah.

b. Sampah.

\subsection{Perancangan Perangkat Keras}

Pada tahap perancangan perangkat keras, akan dilakukan perancangan terhadap arsitektur sistem dan gambaran rangkaian dari sistem Smart Trash Can Berbasis IoT Untuk Petugas Sampah Perumahan.

\subsection{Perancangan Arsitektur Sistem}

Gambaran dari arsitektur sistem Smart Trash Can Berbasis IoT Untuk Petugas Sampah Perumahan yang akan dibangun dapat dilihat pada Gambar 1. 


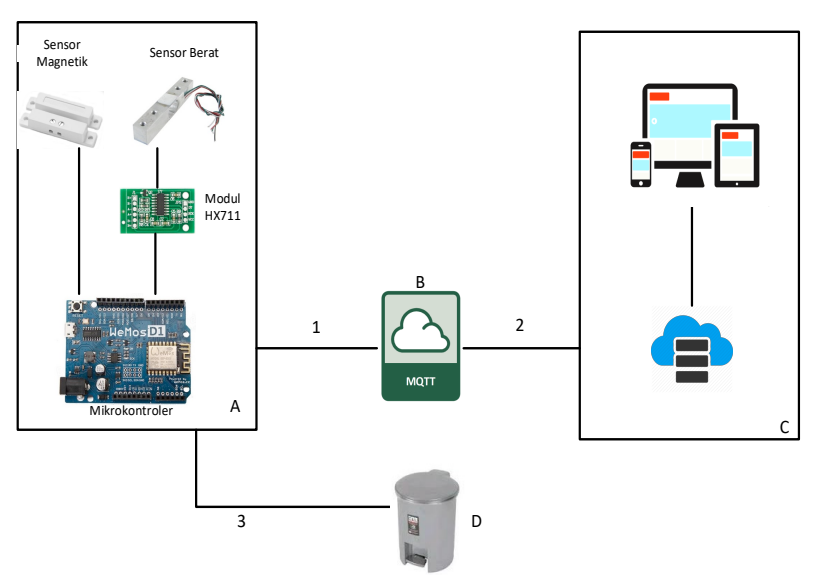

Gambar 1. Arsitektur sistem

Gambar 1. merupakan gambaran arsitektur dari sistem Smart Trash Can Berbasis IoT Untuk Petugas Sampah Perumahan yang akan dibuat pada penelitian ini. Berikut merupakan penjelasan arsitektur sistem pada Gambar 3.2.

A. Perangkat hardware (A)

1. Sensor berat digunakan untuk mendeteksi berat sampah dengan mengkonversi tekanan menjadi sebuah besaran sinyal listrik yang dihubungkan ke sebuah modul.

2. Modul HX711 digunakan untuk konversi sinyal analog ke digital pada sensor berat (load cell) yang terhubung ke mikrokontroler.

3. Sensor magnetic switch bekerja berdasarkan prinsip elektromagnetik yang digunakan untuk mendeteksi bukaan/tutupan tempat sampah yang terhubung ke mikrokontroler.

4. Mikrokontroler digunakan sebagai tempat terhubungnya sensor yang memiliki beban library ESP8266WiFi untuk dapat terkoneksi dengan internet dan library PubSubClient yang digunakan untuk dapat terhubung dengan server broker sebagai client.

B. Sever broker (B) merupakan server yang akan dituju oleh client dalam penyampaian data dimana pengiriman datanya menggunakan protocol MQTT.

C. Server web (C)

1. Laptop/PC (C) adalah perangkat yang dapat digunakan untuk mengakses sistem monitoring berbasis web

2. Database (D) digunakan untuk menyimpan hasil pencatatan data.

D. Smart trash can (E) ini merupakan perangkat yang akan diatur oleh sistem.

Berikut merupakan penjelasan dari hubungan antar perangkat yang terdapat pada Gambar 3.2.
1. Mikrokontroler dan sensor-sensor yang terhubung (A) mengirim nilai sensor yang didapat menuju server broker (B).

2. Sistem web menerima data dari server broker dikarenakan sistem ini terhubung sebagai client.

\subsubsection{Rangkaian Elektronika Sistem}

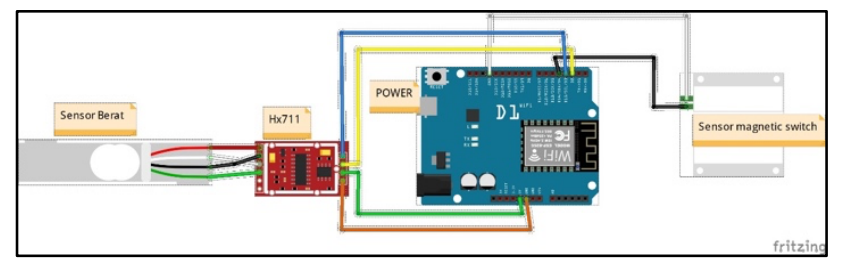

Gambar 2. Gambaran rangkaian sistem

Gambar 3.3 merupakan rangkaian elektronika dari sistem Smart Trash Can Berbasis IoT Untuk Petugas Sampah Perumahan yang akan dibuat pada penelitian ini. Berikut merupakan penjelasan dari masing-masing rangkaian yang terdapat pada Gambar 3.3.

Pada Gambar 3.3 bagian A merupakan rangkaian sensor berat, modul HX711 dan sensor magnetic swicth yang dihubungkan dengan mikrokontroler yang akan diletakan di tempat sampah. Berikut merupakan penjelasan rangkaian yang terdapat pada Gambar 3.3 bagian A.

1. Sensor Berat yang digunakan memiliki 4 buah pin yang terhubung dengan modul HX711. Pin pertama (kabel merah) dihubungkan dengan pin $\mathrm{E}+$ pada HX711 yang merupakan aliran positif $(+)$. Pin kedua (kabel putih) dihubungkan dengan pin $A+$ pada HX711 yang merupakan aliran positif (+). Pin ketiga (kabel hitam) dihubungkan dengan pin E- pada HX711 yang merupakan aliran negatif (-). Pin terakhir (kabel hijau) dihubungkan dengan pin Apada HX711 yang merupakan aliran negative (-).

2. Modul HX711 mempunyai 4 pin yaitu, pin GND (kabel hitam), pin DOUT (kabel biru), pin SCK (kabel ungu) dan pin VCC (kabel merah). Kemudian keempat pin dihubungkan menuju mikrokontroler.

3. Sensor magnetic switch mempunyai 2 pin. Pin pertama (kabel putih) di dihubungkan ke mikrokontroler (GND), kemudian pin kedua (kabel hitam) di hubungkan ke mikrokontroler (D4).

\subsection{Perancangan Perangkat Lunak}

Pada tahap perancangan perangkat lunak, dilakukan perancangan web Smart Trash Can Berbasis IoT Untuk Petugas Sampah Perumahan. Selain 
merancang web, pada tahap ini juga akan dilakukan perancangan arsitektur MQTT sistem.

\subsubsection{Flowchart Alur Kerja Sistem}

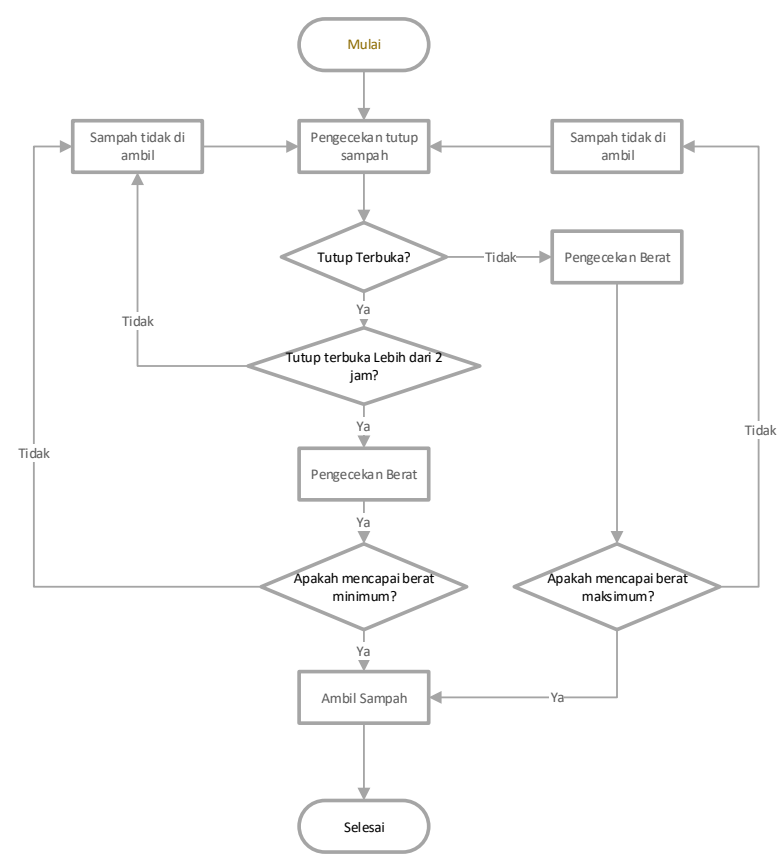

Gambar 3. Flowchart Alur Kerja Sistem

Pada Gambar 3. merupakan flowchart alur kerja sitem dari Smart Trash Can Berbasis IoT Untuk Petugas Sampah Perumahan. Dimulai dari pengecekan tutup tempat sampah, kemudian membaca nilai tutup tempat sampah jika terbuka maka dilakukan pengecekan menuju tutup terbuka lebih dari 2 jam, jika tidak maka dilakukan pengecekan berat menuju pengecekan nilai berat maksimum, kemudian dilakukan pengecekan tutup terbuka lebih dari 2 jam, jika "ya" maka dilakukan pengecekan berat menuju pengecekan nilai berat minimum, jika "tidak" maka sampah tidak diambil. Apabila salah satu dari nilai berat minimum dan maksimum telah mencapai batas maka akan mucul peringatan untuk pengambilan sampah. Dimana, untuk nilai berat minimum tempat sampah adalah 2 kilogram dan nilai maksimum adalah 5 kilogram.

\subsubsection{Sistem Monitoring Berbasis Web}

1. Rancangan Use Case

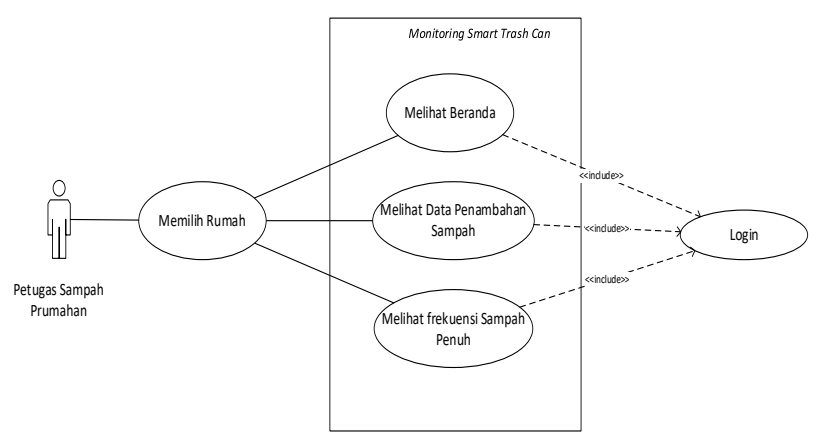

Gambar 4. Use Case Diagram

Pada Gambar 3.5 merupakan use case diagram dari sistem Smart Trash Can Berbasis IoT Untuk Petugas Sampah Perumahan. Dalam sistem ini terdapat satu aktor, yaitu petugas sampah perumahan. Petugas sampah perumahan harus melakukan login terlebih dahulu sebelum dapat memilih rumah, melihat beranda, melihat data penambahan sampah, dan melihat data sampah penuh.

\subsubsection{Rancangan Arsitektur MQTT Sistem}

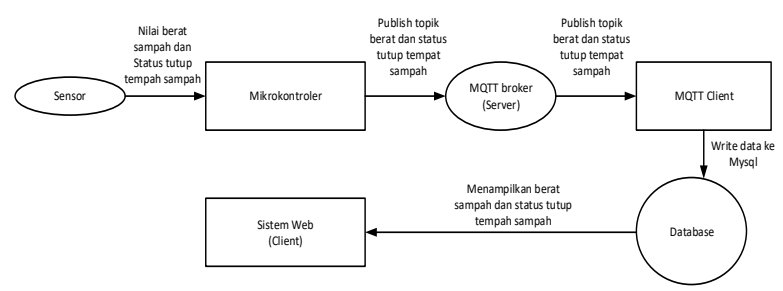

Gambar 5. Use Case Diagram

Pada Gambar 5. merupakan rancangan arsitektur MQTT sistem Smart Trash Can Berbasis IoT Untuk Petugas Sampah Perumahan. Alur proses dimulai dari mikrokontroler membaca data nilai berat dan status tutup tempat sampah dari sensor. Kemudian mikrokontroler mem-publish topik berat dan status tutup tempat sampat sampah ke MQTT broker. MQTT broker akan mem-publish topik berat dan status tutup tempat sampah kepada MQTT client. Kemudian MQTT client akan mengakses ke database yang di tampilkan ke sistem web dan berperan sebagai client yang terhubung dengan MySQL dan MQTT broker. Sistem web ini dapat memantau kondisi tempat sampah secara realtime dan dapat mengakses dan mengelola data yang telah disimpan pada MySQL. 


\section{Hasil dan Pembahasan}

\subsection{Realisasi Sistem}

Pada bab ini, akan membahas hasil dari penelitian yang dilakukan yaitu "Realisasi Sistem Smart Trash Can Berbasis IoT Untuk Petugas Sampah Perumahan". Realisasi sistem ini telah dibuat sesuai dengan perancangan yang dijabarkan pada bab sebelumnya. Kemudian, bab ini juga akan membahas mengenai hasil sistem yang telah dibuat berdasarkan rancangan yang ada, melakukan pengujian keseluruhan sistem dan mengevaluasi sistem yang berjalan.

\subsubsection{Realisasi Penyusunan Perangkat Keras}

Realisasi penyusunan perangkat keras dari Sistem Smart Trash Can Berbasis IoT Untuk Petugas Sampah Perumahan mengacu pada rancangan perangkat keras yang terdapat pada bab sebelumnya. Realisasi perangkat keras yang telah dibuat dapat dilihat pada di bawah ini.

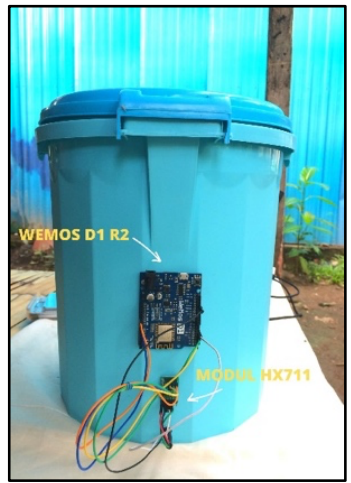

Gambar 6. Realisasi WeMos D1 R1 dan Modul HX711

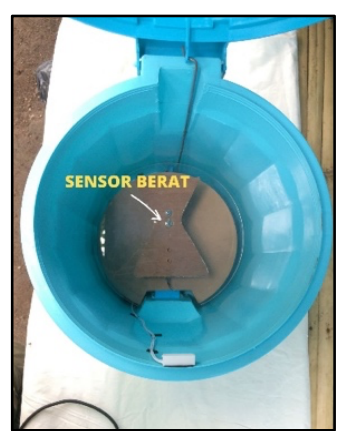

Gambar 7. Realisasi Sensor Berat

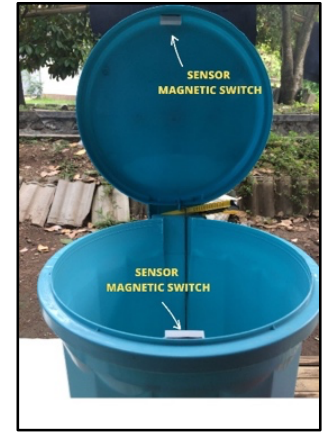

Gambar 8. Realisasi sensor magnetic switch

\subsubsection{Realisasi Pembangunan Web}

Pembangunan web sistem smart trash can berbasis loT ini direalisasikan sesuai dengan rancangan pada bab sebelumnya. Web ini dibangun menggunakan kerangka kerja Codelgniter dengan bahasa pemrograman PHP. Untuk struktur folder pada Codelgniter dapat dilihat pada Gambar 9.

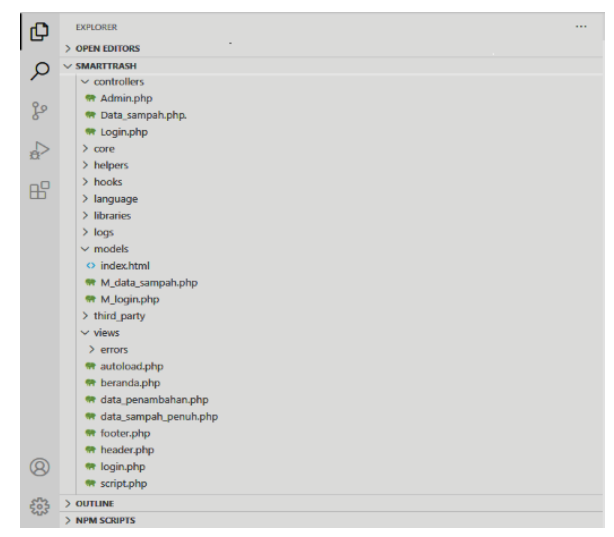

Gambar 9. Folder Struktur Pembangunan Web dengan Codelgniter

\subsubsection{Realisasi Antarmuka Sistem}

Dalam pembangunan web sistem Smart Trash Can Berbasis IoT Untuk Petugas Sampah Perumahan, terdapat satu aktor atau pengguna yang menjalankan sistem sesuai dengan rancangan use case yang terdapat pada bab sebelumnya. Berikut ini merupakan realisasi dari antarmuka sistem web Smart Trash Can Berbasis loT Untuk Petugas Sampah Perumahan. 


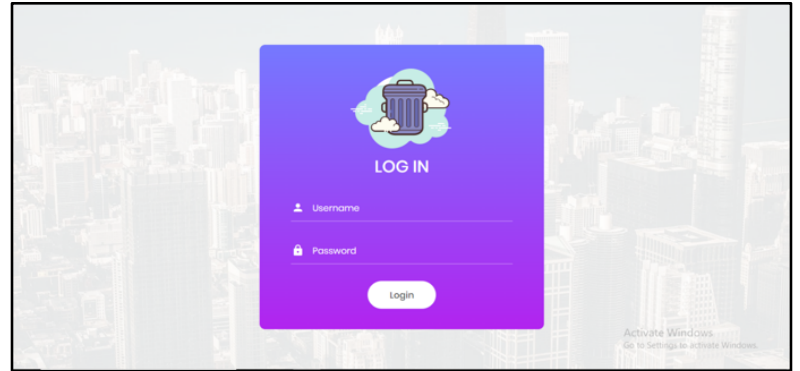

Gambar 10. Halaman Login

Adapun pada Gambar 11. merupakan tampilan dari halaman Beranda, dimana pada halaman ini pengguna dapat melihat status bobot dari tempat sampah yang terhubung dan juga status dari tempat sampah apakah tertutup atau terbuka.

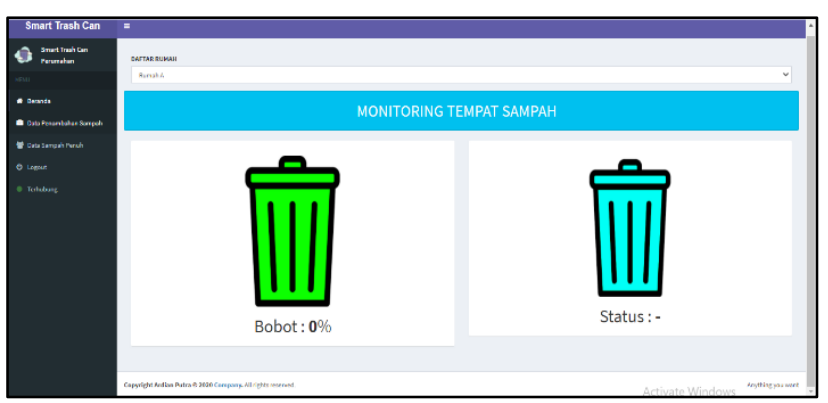

Gambar 11. Halaman Beranda

Adapun pada Gambar 12 merupakan tampilan dimana terlihat kondisi dan mendapatkan nilai bobot sampah yang terisi dan status dari tempat sampah sedang dalam kondisi terbuka.

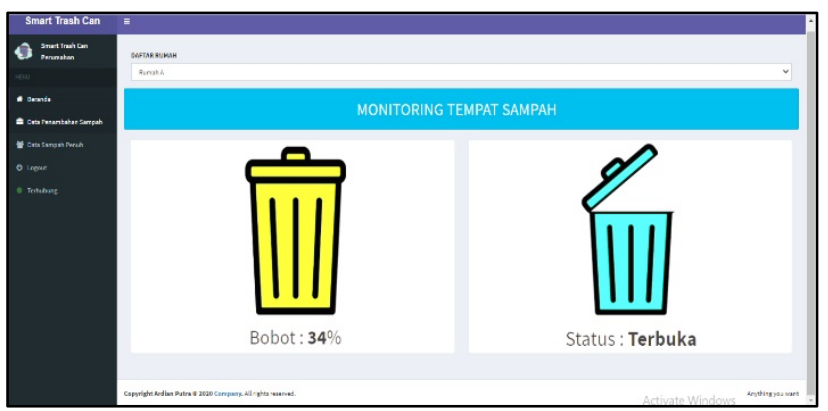

Gambar 12. Halaman Beranda

Adapun pada Gambar 13. merupakan tampilan dimana kondisi bobot sampah sudah mencapai bobot maksimal yaitu sebanyak $100 \%$ dan status dari tempat sampah dalam kondisi tertutup, dimana tampilan diatas juga menunjukkan pemberitahuan berupa sebuah peringatan bahwa sampah sudah terisi penuh.

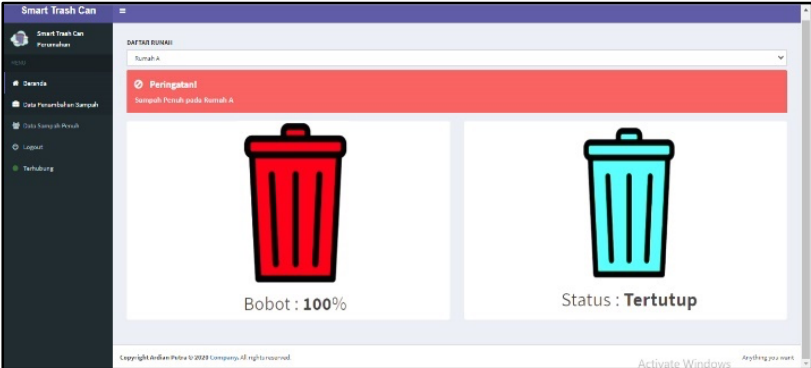

Gambar 13. Halaman Beranda

Adapun pada Gambar 14. merupakan tampilan untuk halaman Data Penambahan Sampah, dimana pada halam ini pengguna dapat mengetahui nilai dari penambahan sampah yang masuk ke dalam sistem. Dimana pada halaman ini dipersentasikan dalam sebuah tabel yang memuat Data Sampah, Waktu, dan Tanggal.

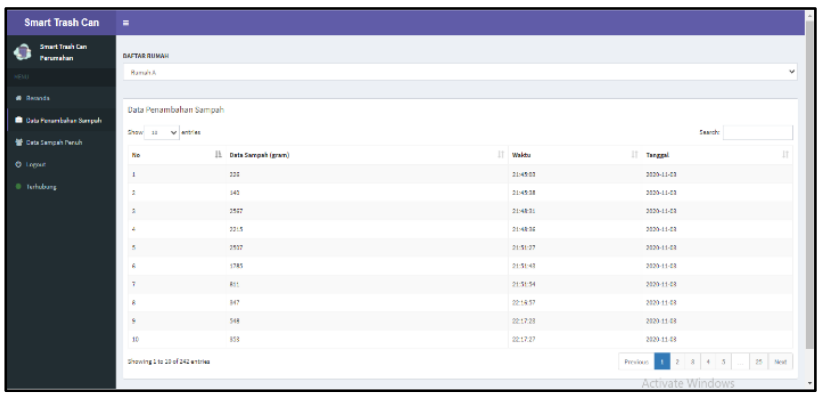

Gambar 14. Halaman data penambahan sampah

Adapun pada Gambar 15. merupakan realisasi antarmuka halaman Data Sampah penuh, dimana pada halaman ini hanya menampilkan untuk data sampah yang penuh saja, pengguna dapat melihat data tersebut dalam bentuk tabel yang memuat Tanggal, Waktu, Berat Sampah (gram), dan Keterangannya.

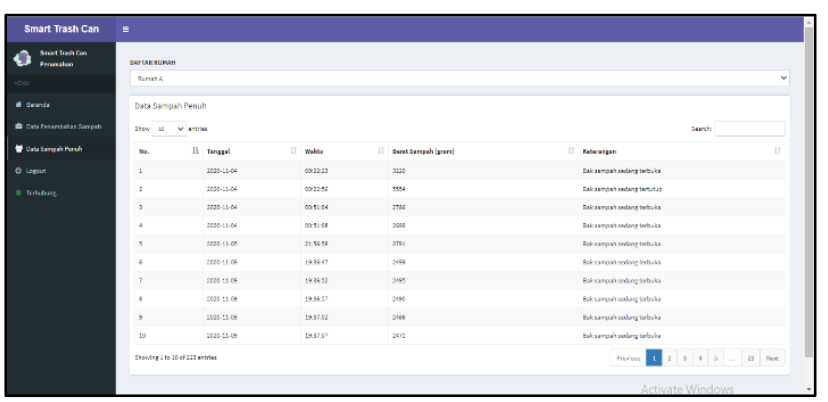

Gambar 15. Halaman data sampah penuh

\subsection{Pengujian dan Realisasi Sistem}

Proses pengujian sistem merupakan proses untuk menguji perangkat keras dan perangkat lunak sistem untuk mengetahui bagaimana sistem berjalan sesuai yang di harapkan. Kemdian untuk proses evaluasi sistem akan dilakukan apabila sistem belum 
berjalan sesuai dengan yang diharapkan peneliti. Proses pengujian perangkat keras dan perangkat lunak sistem dilakukan dengan menguji fungsi dari masingmasing fitur yang ada pada sistem web. Metode yang digunakan dalam proses pengujian sistem ini adalah menggunakan black box dan simulasi.

\subsubsection{Hasil Pengujian Perangkat Keras Sistem}

Proses pengujian sistem Smart Trash Can Berbasis IoT Untuk Petugas Sampah Perumahan ini dilakukan beberapa pengujian untuk masing-masing sensornya sebagaimana dijelaskan sebagai berikut :

\section{Pengujian Sensor Berat}

Pengujian sensor berat dilakukan dengan melakukan beberapa percobaan memasukkan beberapa beban yang memiliki nilai yang berbedabeda dan menyesuaikan dengan percobaan tersebut (kalibrasi) untuk mendapatkan hasil terbaik.

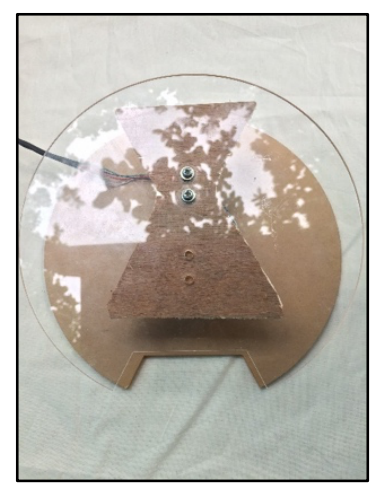

Gambar 16. Pengujian sensor berat

Berikut merupakan hasil dari pengujian sensor berat dengan beberapa kalibrasi agar mendapat hasil yang diinginkan yang dapat dilihat pada Tabel 1 .

TABEL I. HASIL PENGUJIAN SENSOR BERAT

\begin{tabular}{|c|c|c|c|}
\hline No. & Beban (kg) & Hasil Baca & Kesalahan (\%) \\
\hline 1 & 0,1 & 0,1 & 0 \\
\hline 2 & 0,5 & 0,4 & 10 \\
\hline 3 & 1 & 1,1 & 10 \\
\hline 4 & 1,5 & 1,5 & 0 \\
\hline 5 & 2 & 2 & 0 \\
\hline 6 & 2,5 & 2,5 & 0 \\
\hline 7 & 3 & 3 & 0 \\
\hline 8 & 4 & 4 & 0 \\
\hline 9 & 4,5 & 4,5 & 0 \\
\hline 10 & 5 & 5 & 0 \\
\hline
\end{tabular}

Pengujian dilakukan dengan beberapa percobaan dan menyesuaikan dengan percobaan tersebut (kalibrasi) untuk mendapatkan hasil terbaik. Tabel diatas merupakan hasil kalibrasi dengan kesalahan terkecil dari beberapa percobaan. Dari sepuluh kali pengujian yang dilakukan, terjadi 2 kali kesalahan.

Berikut ini merupakan rumus yang digunakan dalam menghitung kesalahan dan total yang didapat:

$$
\begin{aligned}
& \text { Kesalahan }(\%)=\frac{\text { Selisih Beban }}{\text { Beban }} \times 100 \% \\
& \text { Total }=\frac{\text { Banyak kesalahan }}{\text { jumlah pengujian }} \times \sum \% \text { kesalahan }
\end{aligned}
$$

Adapun penyelesaian secara rinci sebagai berikut :

- Kesalahan pada percobaan ke 2 (\%)

$$
\begin{aligned}
& =\frac{\text { Selisih Beban }}{\text { Beban }} \times 100 \% \\
& =\frac{0,1}{0,5} \times 100 \%=20 \%
\end{aligned}
$$

- Kesalahan pada percobaan ke 3 (\%)

$$
\begin{aligned}
& =\frac{\text { Selisih Beban }}{\text { Beban }} \times 100 \% \\
& =\frac{0,1}{1} \times 100 \%=10 \%
\end{aligned}
$$

- Total keseluruhan pengujian sensor

$$
\begin{aligned}
& =\frac{\text { Banyak kesalahan }}{\text { jumlah pengujian }} \times \sum \% \text { kesalahan } \\
& =\frac{2}{10} \times(20+10) \%=6 \%
\end{aligned}
$$

Berdasarkan hasil perhitungan di atas didapatkan total kesalahan pengujian sebesar $6 \%$. Dan dapat disimpulkan bahwa load cell dapat bekerja dengan baik, walaupun terdapat selisih yang sangat kecil antara pengujian dan perhitungan.

\section{Pengujian Sensor Magnetic Switch}

Pengujian sensor magnetic switch merupakan pengujian yang dilakukan dalam realisasi pembangunan sistem Smart Trash Can Berbasis IoT untuk petugas kebersihan perumahan yang menempatkan sensor pada kedua sisi tutup sampah, untuk mendapatkan hasil nilai pada sistem berupa kondisi, apakah tempat sampah dalam keadaan tertutup atau dalam keadaan terbuka. 


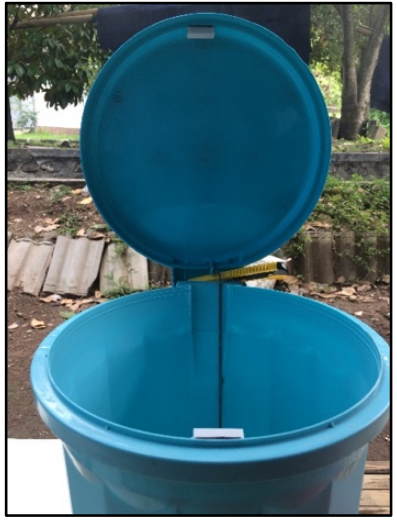

Gambar 17. Pengujian sensor magnetic switch

Berikut merupakan hasil dari pengujian sensor magnetic switch dengan beberapa kondisi yang sesuai dengan nilai input-nya yang dapat dilihat pada Tabel 2.

TABEL II. HASIL PENGUJIAN SENSOR MAgNETIC SWITCH

\begin{tabular}{|c|c|}
\hline Input & Kondisi \\
\hline $\mathbf{0}$ & Tetutup \\
\hline $\mathbf{1}$ & Terbuka \\
\hline
\end{tabular}

Dari hasil pengujian yang di dapatkan dapat diketahui jika nilai input nya merupakan 0 , maka kondisi tempat sampah akan tertutup, sedangkan jika nilai input-nya 1 maka kondisi tempat sampah akan terbuka.

\subsubsection{Hasil Pengujian Sistem Web}

Pada proses pengujian web Smart Trash Can ini dilakukan dengan metode pengujian black box. Pengujian ini dilakukan untuk melihat hasil dari fungsi atau fitur yang ada di dalam web. Berikut merupakan hasil pengujian fungsi dari sistem web yang telah dilakukan.

\section{Pengujian Fungsi Login}

Pengujian fitur login ini dilakukan untuk menguji apakah fungsi yang berjalan pada proses login sudah berjalan dengan baik dan benar. Adapun untuk lebih jelasnya tentang pengujian proses login sistem dapat dilihat pada Tabel 4.3.

TABEL III. HASIL PENGUJIAN FUNGSI LOGIN

\begin{tabular}{|c|c|c|c|c|}
\hline No & $\begin{array}{c}\text { Skenario } \\
\text { Pengujian }\end{array}$ & $\begin{array}{c}\text { Hasil Yang } \\
\text { Diharapkan }\end{array}$ & $\begin{array}{c}\text { Hasil } \\
\text { Pengujian }\end{array}$ & Kesimpulan \\
\hline 1 & $\begin{array}{c}\text { Form } \\
\text { username dan } \\
\text { password diisi } \\
\text { dengan data } \\
\text { yang tidak } \\
\text { sesuai }\end{array}$ & $\begin{array}{c}\text { Proses login tidak } \\
\text { berhasil dan akan } \\
\text { menampilkan } \\
\text { kembali halaman } \\
\text { login }\end{array}$ & Sesuai & Valid \\
& $\begin{array}{c}\text { login } \\
\text { y }\end{array}$ & & \\
\hline
\end{tabular}

\begin{tabular}{|c|c|c|c|c|}
\hline 2 & $\begin{array}{c}\text { Form } \\
\text { username dan } \\
\text { password diisi } \\
\text { dengan data } \\
\text { yang benar }\end{array}$ & $\begin{array}{c}\text { Proses login } \\
\text { berhasil dan akan } \\
\text { masuk pada } \\
\text { sistem yang akan } \\
\text { menampilkan } \\
\text { halaman } \\
\text { dashboard }\end{array}$ & Sesuai & Valid \\
\hline
\end{tabular}

Berdasarkan Tabel 3. Dapat dilihat bahwa untuk semua pengujian proses login menghasilkan kesimpulan yang valid yaitu keseluruhan proses login sudah berjalan dengan semestinya.

\section{Pengujian Logout.}

Pengujian fitur logout ini dilakukan untuk menguji apakah fungsi yang berjalan pada proses logout ini sudah berjalan dengan baik dan benar. Adapun untuk lebih jelasnya tentang pengujian proses logout pada sistem dapat dilihat pada Tabel 4.

TABEL IV. PENGUJIAN PROSES LOGOUT

\begin{tabular}{|c|c|c|c|c|}
\hline No & $\begin{array}{c}\text { Skenario } \\
\text { Pengujian }\end{array}$ & $\begin{array}{c}\text { Hasil yang } \\
\text { diharapkan }\end{array}$ & $\begin{array}{c}\text { Hasil } \\
\text { Pengujian }\end{array}$ & Kesimpulan \\
\hline 1 & $\begin{array}{c}\text { Mengklik } \\
\text { tombol } \\
\text { logout pada } \\
\text { sistem }\end{array}$ & $\begin{array}{c}\text { Proses logout } \\
\text { berhasil dan } \\
\text { menampilkan } \\
\text { halaman login }\end{array}$ & Sesuai & Valid \\
\hline
\end{tabular}

Berdasarkan Tabel 4.4 Dapat dilihat bahwa untuk pengujian proses logout menghasilkan kesimpulan yang valid yaitu sudah berjalan dengan semestinya.

\section{Pengujian Monitoring Tempat Sampah}

Pengujian pada fitur monitoring Smart Trash Can ini dilakukan untuk menguji apakah fungsi pada proses monitoring ini sudah berjalan dengan baik dan benar. Pengujian ini dilakukan dengan cara menampilkan data bobot sampah dan status tutup sampah. Adapun untuk lebih jelasnya tentang pengujian ini dapat dilihat pada Tabel 5.

TABEL V. PENGUIIAN MONITORING TEMPAT SAMPAH

\begin{tabular}{|c|c|c|c|c|}
\hline No & $\begin{array}{c}\text { Skenario } \\
\text { Pengujian }\end{array}$ & $\begin{array}{c}\text { Hasil Yang } \\
\text { Diharapkan }\end{array}$ & $\begin{array}{c}\text { Hasil } \\
\text { Pengujian }\end{array}$ & Kesimpulan \\
\hline \multirow{2}{*}{2} & $\begin{array}{c}\text { Meletekan } \\
\text { beban sampah } \\
\text { pada Smart } \\
\text { Tras Can }\end{array}$ & $\begin{array}{c}\text { Menampilkan } \\
\text { bobot sampah } \\
\text { dalam bentuk } \\
\text { presentase }\end{array}$ & Sesuai & Valid \\
\hline \multirow{2}{*}{2} & $\begin{array}{c}\text { Tidak } \\
\text { menambah } \\
\text { beban pada } \\
\text { Smart Trash } \\
\text { Can }\end{array}$ & $\begin{array}{c}\text { Tidak } \\
\text { bobot sampah } \\
\text { dalam bentuk } \\
\text { presentase. }\end{array}$ & Sesuai & Valid \\
& \multicolumn{2}{|c}{} & \\
\hline
\end{tabular}




\begin{tabular}{|c|c|c|l|l|}
\hline 3 & $\begin{array}{c}\text { Membuka } \\
\text { tutup sampah } \\
\text { Smart Trash } \\
\text { Can }\end{array}$ & $\begin{array}{c}\text { Menampilkan } \\
\text { status tutup } \\
\text { sampah } \\
\text { Terbuka }\end{array}$ & Sesuai & Valid \\
\hline \multirow{4}{*}{4} & $\begin{array}{c}\text { Menutup tutup } \\
\text { sampah Smart } \\
\text { Trash Can }\end{array}$ & $\begin{array}{c}\text { Menampilkan } \\
\text { status tutup } \\
\text { sampah } \\
\text { Tertutup }\end{array}$ & Sesuai & Valid \\
& & & \\
\hline
\end{tabular}

Berdasarkan Tabel 5. Dapat dilihat bahwa untuk semua pengujian pada proses monitoring sudah menampilkan data dalam bentuk angka dan grafik dari masing-masing sensor dengan sesuai. Sehingga proses pada pengujian ini sudah berjalan dengan semestinya.

\section{Pengujian Fungsi Peringatan / Notifikasi sampah} penuh

Pengujian pada fitur Peringatan / Notifikasi sampah penuh dilakukan untuk menguji apakah fungsi Peringatan / Notifikasi sampah penuh sudah berjalan dengan baik dan benar. Pengujian ini dilakukan dengan cara menambah beban sampah $2 \mathrm{~kg}$ dan $5 \mathrm{~kg}$. Adapun untuk lebih jelasnya tentang pengujian ini dapat dilihat pada Tabel 6.

\section{TABEL VI. PENGUJIAN PERINGATAN PENUH}

\begin{tabular}{|c|c|c|c|c|}
\hline No & Skenario Pengujian & $\begin{array}{c}\text { Hasil Yang } \\
\text { Diharapkan }\end{array}$ & $\begin{array}{c}\text { Hasil } \\
\text { Pengujian }\end{array}$ & Kesimpulan \\
\hline 1 & $\begin{array}{c}\text { Menambah beban } \\
2 \text { kg dan tutup } \\
\text { sampah dalam } \\
\text { keadaan terbuka } \\
\text { selama 2 jam }\end{array}$ & $\begin{array}{c}\text { Menampilkan } \\
\text { peringatan } \\
\text { penuh pada } \\
\text { beranda }\end{array}$ & Sesuai & Valid \\
\hline 2 & $\begin{array}{c}\text { Menambah beban } \\
\text { 2kg dan tutup } \\
\text { sampah dalam } \\
\text { keadaan tertutup }\end{array}$ & $\begin{array}{c}\text { Tidak } \\
\text { menampilkan } \\
\text { peringatan } \\
\text { penuh pada } \\
\text { beranda }\end{array}$ & Sesuai & Valid \\
\hline 3 & $\begin{array}{c}\text { Menambah beban } \\
\text { skg dan tutup } \\
\text { sampah dalam } \\
\text { keadaan tertutup }\end{array}$ & $\begin{array}{c}\text { Menampilkan } \\
\text { peringatan } \\
\text { penuh pada } \\
\text { beranda }\end{array}$ & Sesuai & Valid \\
\hline \multirow{2}{*}{$\begin{array}{c}\text { Menambah beban } \\
\text { kurang dari 5kg dan } \\
\text { tutup sampah dalam } \\
\text { keadaan tertutup }\end{array}$} & $\begin{array}{c}\text { Tidak } \\
\text { menampilkan } \\
\text { peringatan } \\
\text { penuh pada } \\
\text { beranda }\end{array}$ & Sesuai & Valid \\
\hline
\end{tabular}

Dari semua pengujian yang dilakukan pada skenario diatas pada fungsi notifikasi/peringatan sudah dapat menampilkan peringatan pada beranda dengan sesuai. Sehingga proses pada pengujian ini sudah berjalan dengan semestinya.

5. Pengujian Fungsi Tabel Data Penambahan Sampah

Pengujian pada fitur fungsi tabel data penambahan sampah dilakukan untuk menguji apakah fungsi pada proses penambahan data sudah berjalan dengan baik dan benar. Adapun untuk lebih jelasnya tentang pengujian ini dapat dilihat pada Tabel 7.

TABEL VII. PENGUJIAN TABEL PENAMBAHAN SAMPAH

\begin{tabular}{|c|c|c|c|c|}
\hline No & $\begin{array}{c}\text { Skenario } \\
\text { Pengujian }\end{array}$ & $\begin{array}{c}\text { Hasil Yang } \\
\text { Diharapkan }\end{array}$ & $\begin{array}{c}\text { Hasil } \\
\text { Pengujian }\end{array}$ & Kesimpulan \\
\hline & $\begin{array}{c}\text { Ada nilai } \\
\text { sampah } \\
\text { yang } \\
\text { disimpan }\end{array}$ & $\begin{array}{c}\text { Fungsi } \\
\text { menampilkan data } \\
\text { berupa tabel } \\
\text { sesuai nilai yang } \\
\text { disimpan }\end{array}$ & Sesuai & Valid \\
\hline 2 & $\begin{array}{c}\text { Tidak ada } \\
\text { nilai yang } \\
\text { disimpan }\end{array}$ & $\begin{array}{c}\text { Fungsi tidak } \\
\text { menampilkan data } \\
\text { dalam tabel }\end{array}$ & Sesuai & Valid \\
\hline
\end{tabular}

Dapat dilihat bahwa untuk semua pengujian pada tabel penambahan sampah sudah menampilkan data dalam bentuk tabel data pembahan sampah. Sehingga proses pada pengujian ini sudah berjalan dengan semestinya.

\section{Pengujian Fungsi Tabel Data Sampah Penuh}

Pengujian pada fitur tabel data sampah penuh dilakukan untuk menguji apakah fungsi tabel data sampah penuh ini sudah berjalan dengan baik dan benar. Adapun untuk lebih jelasnya tentang pengujian ini dapat dilihat pada Tabel 8.

TABEL VIII. PENGUJIAN TABEL SAMPAH PENUH

\begin{tabular}{|c|c|c|c|c|}
\hline No & $\begin{array}{c}\text { Skenario } \\
\text { Pengujian }\end{array}$ & $\begin{array}{c}\text { Hasil Yang } \\
\text { Diharapkan }\end{array}$ & $\begin{array}{c}\text { Hasil } \\
\text { Pengujian }\end{array}$ & Kesimpulan \\
\hline $\begin{array}{c}\text { Ada } \\
\text { peringatan } \\
\text { sampah } \\
\text { penuh yang } \\
\text { disimpan }\end{array}$ & $\begin{array}{c}\text { Fungsi } \\
\text { menampilkan data } \\
\text { sampah penuh } \\
\text { berupa tabel data } \\
\text { sampah penuh }\end{array}$ & Sesuai & Valid \\
\hline 2 & $\begin{array}{c}\text { Tidak ada } \\
\text { peringatan } \\
\text { penuh yang } \\
\text { disimpan }\end{array}$ & $\begin{array}{c}\text { Fungsi tidak } \\
\text { menampilkan data } \\
\text { penuh pada tabel }\end{array}$ & Sesuai & Valid \\
\hline
\end{tabular}

Dapat dilihat bahwa untuk pengujian sudah dapat menampilakan data dalam bentuk tabel. Sehingga proses pada pengujian ini sudah berjalan dengan semestinya.

\subsubsection{Hasil Pengujian Fungsi Keseluruhan Sistem}

Untuk mendapatkan hasil pengujian, perlu adanya skenario pengujian pada perangkat sistem yang dibuat untuk mengetahui apakah sistem dapat berjalan dengan baik atau tidak. Pengujian pada sistem ini dilakukan sesuai dengan skenario yang terdapat pada Tabel 4.9 yakni dengan menguji sistem menggunakan beban yang berbeda-beda. Untuk dapat melihat hasil pengujian fungsi keseluruhan sistem, dapat dilihat sebagai berikut : 
TABEL IX. SKENARIO PENGUJIAN

\begin{tabular}{|c|c|c|c|c|c|}
\hline \multirow{2}{*}{$\begin{array}{c}\text { Skenario } \\
\text { Pengujian }\end{array}$} & $\begin{array}{c}\text { Berat } \\
\text { Sampah } \\
\mathbf{5} 5 \mathrm{~kg} ?\end{array}$ & $\begin{array}{c}\text { Berat } \\
\text { Sampah } \\
\mathbf{2} 2 \mathrm{~kg} ?\end{array}$ & $\begin{array}{c}\text { Tutup } \\
\text { Terbuka } \\
?\end{array}$ & $\begin{array}{c}\text { Ambil Sampah/Tidak } \\
\text { Ambil }\end{array}$ \\
\cline { 5 - 6 } & True & True & True & $\begin{array}{c}\text { Ambetasi } \\
\text { Sampah }\end{array}$ & $\begin{array}{c}\text { Ambil } \\
\text { Sampah }\end{array}$ \\
\hline 2 & False & True & True & $\begin{array}{c}\text { Ambil } \\
\text { Sampah }\end{array}$ & $\begin{array}{c}\text { Ambil } \\
\text { Sampah }\end{array}$ \\
\hline 3 & False & False & True & $\begin{array}{c}\text { Tidak } \\
\text { Ambil }\end{array}$ & $\begin{array}{c}\text { Tidak } \\
\text { Ambil }\end{array}$ \\
\hline 4 & False & False & False & $\begin{array}{c}\text { Tidak } \\
\text { Ambil }\end{array}$ & $\begin{array}{c}\text { Tidak } \\
\text { Ambil }\end{array}$ \\
\hline 5 & True & True & False & $\begin{array}{c}\text { Ambil } \\
\text { Sampah }\end{array}$ & $\begin{array}{c}\text { Ambil } \\
\text { Sampah }\end{array}$ \\
\hline
\end{tabular}

Berdasarkan skenario pengujian yang dilakukan pada Tabel 4.9 didapatkan kesimpulan bahwa skenario yang dilakukan sudah berjalan sebagaimana mestinya. Hal ini dapat dibuktikan pada Tabel 4.10 dan Tabel 4.11 yang merupakan hasil dari data yang telah di simpan pada database yang ada dalam sistem website. Berikut hasil data dari pengujian pada sistem :

TABEL X. DATA PENAMBAHAN SAMPAH

\begin{tabular}{|c|c|c|c|c|}
\hline No & Id & Berat (gram) & Waktu & Tanggal \\
\hline 1 & 4 & 226 & $21: 45: 03$ & $2020-11-03$ \\
\hline 2 & 5 & 140 & $21: 45: 38$ & $2020-11-03$ \\
\hline 3 & 6 & 2567 & $21: 48: 31$ & $2020-11-03$ \\
\hline 4 & 7 & 2215 & $21: 48: 36$ & $2020-11-03$ \\
\hline 5 & 8 & 2507 & $21: 51: 27$ & $2020-11-03$ \\
\hline 6 & 9 & 1785 & $21: 51: 43$ & $2020-11-03$ \\
\hline 7 & 10 & 811 & $21: 51: 54$ & $2020-11-03$ \\
\hline 8 & 11 & 347 & $22: 16: 57$ & $2020-11-03$ \\
\hline 9 & 12 & 548 & $22: 17: 23$ & $2020-11-03$ \\
\hline 10 & 13 & 353 & $22: 17: 27$ & $2020-11-03$ \\
\hline 11 & 14 & 1308 & $22: 17: 47$ & $2020-11-03$ \\
\hline 12 & 15 & 2695 & $22: 17: 52$ & $2020-11-03$ \\
\hline 13 & 82 & 542 & $00: 21: 05$ & $2020-11-04$ \\
\hline 14 & 83 & 4495 & $00: 21: 10$ & $2020-11-04$ \\
\hline 15 & 84 & 3136 & $00: 21: 15$ & $2020-11-04$ \\
\hline 16 & 85 & 2193 & $00: 22: 13$ & $2020-11-04$ \\
\hline 17 & 86 & 3223 & $00: 22: 18$ & $2020-11-04$ \\
\hline 18 & 87 & 2647 & $00: 22: 48$ & $2020-11-04$ \\
\hline 19 & 88 & 5554 & $00: 22: 56$ & $2020-11-04$ \\
\hline 20 & 89 & 5604 & $00: 22: 57$ & $2020-11-04$ \\
\hline
\end{tabular}

Pada Tabel 10. merupakan tabel yang menunjukan hasil penambahan sampah di dalam sistem smart trash can berbasis IoT untuk petugas sampah perumahan, untuk kolom yang pertama yaitu kolom id merupakan id untuk masing-masing penambahan data baru yang masuk, selanjutnya untuk kolom kedua merupakan kolom yang menunjukan berat dari jumlah setiap penambahan sampah yang masuk, jadi untuk setiap penambahan sampah sistem akan mencatat setiap nilai berat yang belum termasuk ke dalam kategori penuh dalam bentuk gram. Selanjutnya untuk kolom waktu, merupakan kolom yang mencatat waktu masuk nilai berat sampah ke dalam sistem, jadi untuk setiap penambahan sampah sistem akan mencatat waktunya.
Sama halnya seperti waktu, pada kolom tanggal memuat data berupa tanggal, bulan dan tahun ketika data sampah di tambahkan, jadi setiap kali penambahan data sampah maka sistem akan menacatat tanggal data ditambahkan.

TABEL XI. DATA SAMPAH PENUH

\begin{tabular}{|c|c|c|c|c|}
\hline No & Tanggal & Waktu & Berat(gram) & Keterangan \\
\hline 1 & $2020-11-04$ & $00: 51: 04$ & 2786 & $\begin{array}{c}\text { Bak sampah } \\
\text { sedang terbuka }\end{array}$ \\
\hline 2 & $2020-11-04$ & $00: 22: 56$ & 5554 & $\begin{array}{c}\text { Bak sampah } \\
\text { sedang tertutup }\end{array}$ \\
\hline 3 & $2020-11-04$ & $00: 51: 04$ & 2786 & $\begin{array}{c}\text { Bak sampah } \\
\text { sedang terbuka }\end{array}$ \\
\hline 4 & $2020-11-09$ & $20: 22: 25$ & 5038 & $\begin{array}{c}\text { Bak sampah } \\
\text { sedang tertutup }\end{array}$ \\
\hline 5 & $2020-11-09$ & $20: 43: 25$ & 5018 & $\begin{array}{c}\text { Bak sampah } \\
\text { sedang terbuka }\end{array}$ \\
\hline 6 & $2020-11-12$ & $18: 02: 28$ & 3185 & $\begin{array}{c}\text { Bak sampah } \\
\text { sedang terbuka }\end{array}$ \\
\hline 7 & $2020-11-09$ & $19: 36: 47$ & 2499 & $\begin{array}{c}\text { Bak sampah } \\
\text { sedang terbuka }\end{array}$ \\
\hline 8 & $2020-11-12$ & $17: 44: 25$ & 5006 & $\begin{array}{c}\text { Bak sampah } \\
\text { sedang tertutup }\end{array}$ \\
\hline 9 & $2020-11-12$ & $18: 08: 22$ & 3183 & $\begin{array}{c}\text { Bak sampah } \\
\text { sedang terbuka }\end{array}$ \\
\hline 10 & $2020-11-12$ & $19: 53: 28$ & 3222 & $\begin{array}{c}\text { Bak sampah } \\
\text { sedang terbuka }\end{array}$ \\
\hline
\end{tabular}

Pada Tabel 4.11 merupakan tabel yang menujukan data untuk data penambahan sampah dalam kategori penuh, dalam sistem tabel ini hanya akan mencatat penambahan sampah jika sudah mencapai batas maksimal yang sudah ditentukan yaitu jika tempat sampah dalam keadaan terbuka sistem akan mencatat tempat sampah penuh jika data berat sampah mencapai minimal lebih dari $2 \mathrm{~kg}$ dan untuk tempat sampah dalam keadaan tertutup sistem akan mencatat tempat sampah penuh jika data berat sampah mencapai minimal lebih dari $5 \mathrm{~kg}$. Sama hal nya dengan tabel sebelumnnya, pada tabel ini mencatat data seperti tanggal, waktu dan data nilai berat sampah penuh.

\subsubsection{Hasil Pengujian dengan Metode Mean Opinion Score (MOS)}

Pengujian metode MOS dilakukan dengan bantuan responden dari petugas sampah perumahan serta masyarakat di perumahan Babakan Permai dengan memberikan gambaran sistem dan kuesioner. Yang bertujuan umtuk mengetahui bagaimana kualitas sistem dari sisi pengguna dan masyarakat perumahan. Adapun kuesioner yang diberikan sebagai berikut : 
1. Apakah sistem Smart Trash Can berbasis loT dapat berjalan dengan baik dan sesuai dengan harapan?

2. Apakah sistem monitoring pada sistem Smart Trash Can berbasis loT dapat memberikan informasi mengenai bobot sampah dan status tutup sampah?

3. Apakah fungsi tabel data penambahan sampah dan data sampah penuh dapat memudahkan pengguna mendapatkan informasi data sampah?

4. Apakah sistem ini dapat membantu atau memudahkan manajemen pengangkutan sampah pada perumahan Babakan Permai?

5. Apakah antarmuka dari sistem monitoring Smart Trash Can berbasis web ini mudah dipahami dan digunakan (user friendly)?

Responden yang terlibat dalam penelitian yaitu 20 orang dengan jumlah laki-laki sebanyak 9 orang dan perempuan sebanyak 11 orang. Hasil pengujian parameter MOS yang diperoleh dapat dilihat pada Tabel 4.13.

TABEL XII. HASIL PENGUJIAN MOS.

\begin{tabular}{|c|c|c|c|c|c|c|c|c|}
\hline No. & Questions & $\begin{array}{l}\text { SS } \\
\text { (5) }\end{array}$ & $\begin{array}{c}S \\
(4)\end{array}$ & $\begin{array}{l}\text { TT } \\
\text { (3) }\end{array}$ & $\begin{array}{l}\text { TS } \\
\text { (2) }\end{array}$ & $\begin{array}{l}\text { STS } \\
\text { (1) }\end{array}$ & Sum & $\begin{array}{c}\text { Mean } \\
\text { pi }\end{array}$ \\
\hline 1 & Ke-1 & 13 & 7 & - & - & - & 20 & 4.65 \\
\hline 2 & Ke-2 & 15 & 5 & - & - & - & 20 & 4.75 \\
\hline 3 & Ke-3 & 8 & 12 & - & - & - & 20 & 4.40 \\
\hline 4 & $\mathrm{Ke}-4$ & 10 & 10 & - & - & - & 20 & 4.50 \\
\hline 5 & Ke-5 & 12 & 8 & - & - & - & 20 & 4.60 \\
\hline \multicolumn{2}{|c|}{ Sub Total } & 58 & 42 & - & - & - & 100 & 22.90 \\
\hline \multicolumn{8}{|c|}{ MOS (Mean Opinion Score) } & 4.58 \\
\hline
\end{tabular}

Berikut ini merupakan rumus yang digunakan dalam menghitung skor rata-rata dari bobot nilai yang didapat :

$$
\text { mean } p i=\frac{\sum S i \cdot B i}{n}
$$

di mana :

mean $\mathrm{pi}$ = rata-rata skor setiap atribut pertanyaan

$\mathrm{Si} \quad=$ responden memilih setiap atribut jawaban

$\mathrm{Bi} \quad=$ bobot setiap atribut pertanyaan

$\mathrm{n} \quad=$ jumlah responden

Untuk mendapatkan nilai MOS (Mean Opinion Score) berdasarkan skor rata-rata yang didapat, dapat digunakan rumus berikut :

$$
M O S=\frac{\sum_{i=1}^{k} \operatorname{mean} p i}{k}
$$

Keterangan :

MOS = total skor rata-rata seluruh atribut pertanyaan

$\mathrm{K}=$ jumlah atribut pertanyaan

Pada pengujian MOS menunjukan hasil bahwa nilai MOS yang didapatkan yaitu sebesar 4.50 dari skala 5 yang menunjukan bahwa sistem yang dibangun sudah cukup baik dan sudah dapat berjalan sesuai apa yang diharapkan.

\section{KESIMPULAN DAN SARAN}

\subsection{Kesimpulan}

Berdasarkan penelitian yang telah dilakukan, maka kesimpulan yang dapat diambil dari penelitian ini adalah sebagai berikut :

1. Rangkaian elektronika Smart Trash Can yang dibuat sudah bisa melakukan monitoring untuk tempat sampah yang menampilkan bobot sampah dan status tutup sampah.

2. Sistem web yang dibangun telah dapat melakukan monitoring dengan menampilkan data penambahan sampah dan data sampah penuh dari masing-masing sensor yang ditampilkan dalam bentuk tabel.

3. Komunikasi data menggunakan protokol MQTT telah berjalan dengan baik, dengan menggunakan "broker.hivemq.com" sebagai broker online yang bersifat open source.

4. Sistem yang dibangun diuji menggunakan 5 skenario pengujian untuk mengetahui sistem berjalan dengan baik atau tidak, dan didapatkan kesimpulan bahwa alat dan sistem bekerja dengan baik.

5. Hasil pengujian MOS yang telah dilakukan dapat diperoleh nilai sebesar 4.58 dari skala 5 yang menunjukan bahwa sistem yang dibangun sudah termasuk dalam kategori baik

\subsection{Saran}

Jika dilakukan penelitian lebih lanjut tentang penelitian ini dapat mempertimbangkan saran-saran sebagai berikut :

1. Untuk pengembangan selanjutnya diharapkan menggunakan variasi tempat sampah yang berbeda atau lebih besar.

2. Diharapkan kedepannya sistem dapat dibangun berbasis mobile agar notifikasi sampah bisa lebih cepat diakses oleh petugas sampah. 
3. Sistem ini diharapkan dapat dikembangkan menjadi sistem yang dapat membedakan sampah organik dan non organik.

\section{DAFTAR PUSTAKA}

[1] E. Damanhuri and T. Padmi, Diktat Kuliah Pengelolaan sampah. Program Studi Teknik Lingkungan, Institut Teknologi Bandung, 2010.

[2] S. Keman, "Soedjajadi Keman, Kesehatan Perumahan," J. Kesehat. Lingkung. Univ. Airlangga, vol. 2, pp. 29-43, 2005, doi: 10.1111/j.18347819.2006.tb00442.x.

[3] E. D. Meutia, "Internet of Things - Keamanan dan Privasi," Semin. Nas. dan Expo Tek. Elektro 2015, pp. 85-89, 2015.

[4] Mufti and Indra, "Rancang bangun tempat sampah pintar menimbang dan mengenali jenis sampah pada bank sampah budi luhur 1,2," J. Teknol. Inf. . Univ. Budi Luhur, pp. 1-6, 2012.

[5] Y. B. Widodo, T. Sutabri, and L. Faturahman, "Tempat sampah pintar dengan notifikasi berbasis iot," J. Teknol. Inform. dan Komput., vol. 5, no. 2, 2019.

[6] Z. A. Zhafira, Z. Doni and Herryawan P, "Analisis dan Rancang Bangun Sistem Monitoring Tempat Sampah Berbasis IOT menggunakan Protokol MQTT," J. Proc. Conf. Electr. Eng. Telemat. Ind. Technol. Creat. Media, pp. 302-307, 2018.

[7] R. Ganda, "Rancang Bangun Tempat Sampah Pintar Menggunakan Sensor Jarak Berbasis Mikrokontroler Atmega 328," Dept.Fisika, Univ. Sumartra Utara, p. 20, 2018.

[8] N. Mayun, K. S. Dewa, and Yasmara I N., "Manajemen Pengangkutan Sampah di Kota Amlapura," J. Ilm. Tek. Sipil Vol. 13, No. 2, vol. 13, no. 2, pp. 120-135, 2009.

[9] S. Kurniawati ., Z. Una and Munawarah P., "IbM Kota Mataram Yang Mengalami Masalah Sampah Rumah Tangga," Junal Pengabdi. Kpd. Masy. IKIP Mataramnal Pengabdi. Kpd. Masy. IKIP Mataram, vol. 2, pp. 37-41, 2017.

[10] M. Pamungkas, Hafiddudin, and Y. S. Rohmah, "Perancangan dan Realisasi Alat Pengukur Intensitas Cahaya," J. Elkomika, vol. 3, no. 2, pp. 120-132, 2015, doi: 10.26760/elkomika.v3i2.120.

[11] A. Isnaeni, "Rancang Bangun Smarthome Menggunakan Chat Bot," Universitas Islam Negeri Alauddin Makassar, 2018.

[12] A. Rahman and M. Nawawi, "Perbandingan Nilai Ukur Sensor Load Cell pada Alat Penyortir Buah
Otomatis terhadap Timbangan Manual," vol. 5, no. 2, pp. 207-220, 2017.

[13] S. Siswanto, G. P. Utama, and W. Gata, "Pengamanan Ruangan Dengan Dfrduino Uno R3, Sensor Mc-38, Pir, Notifikasi Sms, Twitter," J. RESTI (Rekayasa Sist. dan Teknol. Informasi), vol. 2, no. 3, pp. 697-707, 2018, doi: 10.29207/resti.v2i3.592.

[14] F. K. R. Mahfud, A. D. Afrizal, F. A. Pribadi, F. J. Pamungkas, and G. Y. Saputra, "Penerapan Protokol MQTT Pada Teknologi Wan (Studi Kasus Sistem Parkir Univeristas Brawijaya)," Inform. Mulawarman J. IIm. IImu Komput., vol. 12, no. 2, p. 69,2018 , doi: $10.30872 /$ jim.v12i2.653. 